\title{
"Employee-Development Practices in Iran: Effort to enhance level of Human Capital- a Study"
}

\author{
Masoud Ghorbanhosseini \\ Islamic azad university, Saveh branch, Saveh,Iran \\ mqorban@gmail.com
}

\begin{abstract}
The most significant resource of any organization is its people. An organization is nothing but interrelated groups of people whose activities are planned and coordinated to meet organizational objectives. A worker is a man; he possesses potential of being dangerous as well as an exceptionally useful person; he canmake or mar the organisation. Therefore, there is need to establish the right type of working climate to promote and maximize employee-motivation and commitment, and also to evolve strategies to blossom his potential. An organization has a good chance to survive and prosper if it consists of the right people. People have to be trained, re-trained and developed with planned effort.

This article relates to result of study on the work-culture and 'Employee Development Practices' forenhancing level of Human Capital in 'SAFA' Industrial Group' in Iran, on parameters like Employee mind-set, teamwork,participation, responsibility-bearing, commitment, training and development.
\end{abstract}

Key words: Corporate Citizenship, Engagement, Commitment, Holistic Development,Involvement, Participation.

\section{Introduction}

Organizations encounter several obstacles in meeting their goals and in a similar way, all employees report some problems in their attempts to be productive and efficient in their jobs, and to feel satisfied in their work-lives. The challenge to human resources management is to minimize these obstacles and problems. In other words, there is need on the part of employees to maintain 'work-life' balance; the organizations have to render help in this regard to win the hearts of the people and thereby reap rich dividends in the form of achievement of organization objectives. The organisation/management prepares a Human Resource Development Plan to develop their human resources - they proudly call it as 'Human Capital'.

The culture of an organization is the product of all itsfeatures - its people, objectives, size, technology, workers' unions, policies, practices, its successes and failures as well as the sum total of shared values, beliefs and habits within an organization. In short, this composite whole may be called the personality of an organization.

After employees have been selected for various positions in an organization, their training is important. It is to train them for the specific tasks to which they have been assigned. Many organizations believe that before an employee is fitted into a harmonious working relationship with other employees, he is to be given adequate training. Training is an important activity in many organizations. We generally see when a new machine is installed in a factory, it is operated on trial basis before going into actual production. We know that equipment needs a breaking-in period; similarly, a new employee needs training and existing ones re-training to adjust to the new or changing environment.

Defining Training: According to Edwin D. Flippo (1984, p. 51), training is the act of increasing the knowledge and skills of an employee for doing a particular job. The major outcome of training is learning. ${ }^{1}$ It means that a trainee learns new habits, new or refined skills and useful new knowledge (or updates it) during the training programme that help him how to improve performance. Training enables an employee to do his present job more efficiently and also prepares him for a higher-level job. Training, thus, may be defined as a planned programme designed to improve performance and bring about measurable changes in knowledge, skills, attitude and social behaviour of employees.

Basically, training is understood as a learning experience that is planned and carried out by the organization to enable more skilled task behaviour from the trainee. Training creates the ability to detect and correct errors. It also provides skills and abilities that may be called on in the future to satisfy the organization's human resource needs. Training may be carried out on the job or in the classroom. In the latter case, it may be on-site or off-site, perhaps in a module or a training centre or it may be in a simulated environment that is

${ }^{1}$ Flippo, Edwin, D. (1994).Personnel Management. McGraw Hill, New York.p.51. 
thought to be similar to the work environment in important respects. In any case, trainees are expected to acquire abilities and knowledge that would enable them to perform their jobs more effectively.

Features of Training

- Training increases knowledge and skills for doing a job.

- It bridges the gap between job needs and employee skills, knowledge and behaviour

- It teaches Job-oriented process that is vocational in nature.

- It is short-term activity designed essentially for operatives.

Training vs. Development:Training often has been referred to as teaching specific skills and behaviour. Examples of training are learning to fire a rifle, to shoot fine shots in basketball and to type. It is usually reserved for people who have to be brought up to performing level in some specific skills. The skills are almost always behavioural as distinct from conceptual or intellectual. However, Development is considered to be more general than training and more oriented to individual needs in addition to organizational need. Development is most often aimed towards management people. Usually, development is to provide knowledge and understanding that will enable people to carry out non-technical organizational functions more effectively, such as problem solving, decision making and relating to people. Garry Dessler (2005) says about development as "Management development is any attempt to improve managerial performance by imparting knowledge, changing attitudes, or increasing skills". ${ }^{2}$

\section{Training vs. Education}

We know that the term 'education' is wider in scope and more general in purpose when compared to training. Training is the act of increasing the knowledge and skills of an employee while doing a job. It is joboriented (skill learning). Education, on the other hand, is the process of increasing the general knowledge and understanding of employees. It is person-oriented, theory-based knowledge, main purpose of which is to improve the understanding of a particular subject or theme (conceptual learning). Its primary focus is not the job of an operative. Education is imparted through schools or colleges and the contents of such a programme generally aim at improving the talents of a person. Training is practice-based (repetitive action) and company specific. However, both have to be viewed as programmes that are complementary and mutually supportive. Both aim at harnessing the true potential of a person/employee.

"The basic purpose of training programme is to provide the participants with the requisite knowledge to achieve the goals of the job ....... For instance, when the organisation finds the existing skills and knowledge of the staff inadequate to achieve the strategic goals and objectives, training is considered ". ${ }^{3}$

\section{Current Literature}

Sohel Ahmad and Roger G. Schroeder (2003), in their published Article said, "Specifically, the mediating effect of organisational commitment which helps us better understand the nature of the relationship between HRM practices and organisational performance". 4

Krystyna Joanna Zaleska and Lilian M. de Menezes, in their published Article (2007) said, “...... The companies have to implement practices that enhance development opportunities for older and low-skilled workers. So far what they receive tends to be narrow and task specific. ...... More skill is needed across the wider workforce and its various groups, who can also exercise creativity in order to add competitive value (Craig and Hall, 2005). ${ }^{5}$

MaranMarimuthu, et al (2009) asserted in their published Article, stated, “..........the infusion of 'human capital enhancement' in organisations promotes innovativeness and greater firm performance. Firm performance can be viewed in two different perspectives: financial performance and non-financial performance. Financial Performance includes productivity, innovation, market share and profitability, whereas, non-financial performance includes customer satisfaction, innovation, work-flow improvement and skills development". ${ }^{6}$

\footnotetext{
${ }^{2}$ Gary Dessler, (2005). Human Resource Management, Pearson education, Delhi. Pp. 285-286.

${ }^{3}$ Armstrong, Michael, (2001). A Handbook of Human Resource Management Practice, $8^{\text {th }}$ ed. Kogan Page, London. Pp.579-581.

${ }^{4}$ Sohel Ahmed and Roger G. Schroeder. (2003). The Impact of Human Resource management practices on operational Performance: recognising country and industry differences. ELSEVIER Journal of Operations Management. No. 21, pp. 19-43.
}

${ }^{5}$ Craig, E. F. and Hall, D. T. The New Organisational Career: Too important to be left to HR? In: Burke, R. J. and Cooper, C. L. (eds.). (1996). The Boundryless Career: A new Employment Principle for a New Organisational Era. Oxford University Press, Oxford. Pp. 187 200.

${ }^{6}$ MaranMarimuthu. (2009).Human Capital Development and its Impact on Firm Performance: Evidence From Developmental Economics;UluslararasiSosyalArastimanalarDergisi, The Journal of International Social Research: Vol 2/8 - Summer . 
Birasnav, M. and S. Rangnekar, in their published Article (2009), said, "These investment (HR investments) methods were reward strategy to reinforce employees' consistent innovative behaviours, careeroriented training to advance employees' career within the firm, performance appraisal to improve required skills of employees, recruitment strategy to increase the stock of human capital, career management to improve developmental behaviors of employees, and performance-oriented training to develop skills and knowledge of employees. ........." .

On Employee-engagement, Geetha Jose, Sebastian Rupert Mampilly (2012), in their published Article, said "....based on review, this study suggests that an engaged employee is the one who is optimistic, highly focused on his work, enthusiastic and willing to go an extra mile to contribute to sustainable organisational success on a long-term basis". ${ }^{8}$

On need for Training and Development, LalBahadurBaniya (2004), in his published Article, said, "Training is the only development opportunity provided for employees to develop their knowledge, skills, and abilities. Both on-the-job and off-the-job training are made available to the employees". He further says, "Management is always suspicious about employees. They

have a feeling that after training, employees leave for better job. Employees put forth a view that this generalization should not be made for all on the pretext of a few". 9

RosemondBoohene (2011), in his published Article, said about Management Practices on Corporate Performance that "....performance could be explained by its effective recruitment and selection practices and Performance Appraisal practices".

According to PravinDurai (2010, p183), "In this age, the organisation undertakes the necessary efforts to gradually expose the new employees to the prevailing organisational culture. This is done by facilitating the employees to learn the relevant values, beliefs and attitudes. When the pre-acquired values of the employees and the organisational culture are similar, the socialisation process becomes simple as it can easily help the employees assimilate the organisational culture and values. In contrast, the socialisationprogramme becomes critical when there are divergences in the new employees' values and the organisational culture ....".

Other literature references touching upon specific situations in a few cases in the corporate world are mentioned below:

Balaji (2012), in his published Article, mentioned the tragic episode relating to Maruti-Suzuki India Limited. He narrated that in the company's Manesar plant/unit in District Gurgaon (Haryana) in India, due to Workers' violence, the General Manager of HR Department had been burnt alive after criminal assault; which resulted in the loss of Company's property worth INR 100million, and loss of production of the order of INR 14,000 million in 10-day lock-out and about 60 days closure enforced by the company to restore the facilities to normalcy. As many as 500 workers were served show-cause notices and an equal number fired for violent activities. ${ }^{10}$

PankajTiwari (2012), in his published Article asserted that “ .........HRM practices, such as working in teams, greater discretion and autonomy in the workplace and various employee-involvement and pay schemes, do motivate workers and generate higher labour productivity (Cully et al , 1999; Boslie and Wiele, 2002). ${ }^{11}$

This goes to show how human resource could turn violent and caused suffering to the families, damage the facilities and harm the public interest as well as loss of revenue to the government by way of less tax collections. The company raised the price of cars by about $1.5 \%$ to compensate itself for the loss of profits. The financial burden fell obviously upon the customers who had to shell out higher prices for cars.

This incident proves that the attitude of the workmen (Human resource) cannot be gauged and predicted precisely and accurately. The HR Manager/functionary has to be alert to use the grapevine (informal) for timely action to avoid matters taking an ugly turn. Human resource can be transformed into human capital and their morale improved and motivation boosted as they can make or mar the organisation.

Other literature references touching upon specific situations in a few cases in the corporate world are mentioned below:

Let me mention here another case - that of Xerox (quoted by Balaji, 2012). It got trapped into debt-trap and its debts mounted to staggering figure of USD 17 billion in 2000; its share prices plunged to abysmally low

\footnotetext{
${ }^{7}$ Birasnav, M. and S. Rangnekar.(2008). A Conceptual Model of Human Capital Creation. In: Chundawat, D. S., Saxena, K. and Bhadu, S. S. (Eds.). Managing Global Competition: A Holistic Approach. MacMillan, New Delhi. Pp. 261-273.

${ }^{8}$ Geetha Jose, Sebastian Rupert Mampilly (2012).

${ }^{9}$ Baniya, LalBahadur. (2004). Human Resource Development Practices in Nepalese Business Organisations: A Case Study of Manufacturing Enterprises in Pokhara. The Journal of Nepalese Business Studies, Vol. 1. December, 2004.

${ }^{10}$ Balaji.(2012). Maruti Episode in Manesar in Gurgaon.IJEMR. Issue No.8, August, 2012.

${ }^{11}$ Tiwari, Pankaj. (2012). Human Resource Management Practices: A Comparative Review. Pakistan Business Review. January, 2012.
} 
level t USD 4 in the same year. The Company staged a surprising comeback in 2003 when its profits improved to USD 222 million. ${ }^{12}$

Yet another case may be cited - that of Japan Airlines (JAL), (also quoted by Balaji, 2012) which went red until September 2011. The Company went under heavy debt equivalent of about INR 12, 80,000 million (INR 1, 28, 000). Consequently, its share prices fell sharply. Inamori, the most celebrated entrepreneur and man of extraordinary calibre in Japan, took over the reins of JAL in October 2011. He made policy changes and evolved strategic Planning, and thereby, with the co-operation of workers/employees succeeded in making a turnaround in the most remarkable and impressive manner. The man of extra-ordinary brains and keen business acumen sought the needed support of the staff and undertook route-wise profitability study, and identified routes that were incurring losses. He also found bloated workforce in the organisation. He attacked both these weakpoints and succeeded in earning profits thereafter. ${ }^{13}$

A few years back, State Bank of India had a very highly dynamic Chairman, Mr. O. P. Bhat, who diagnosed the problem of low level commitment of staff at its 13,000 odd branches; the customer service was also found at low ebb. Bank's image was not projected well in keeping with its pioneer-position in the banking industry. It was a matter of concern for Mr. Bhat who held repeated consultations with both the All India SBI Employees' Federation and the All India Officers' Federation to convince them to work jointly for improving matters. He got all the employees and officers at all the over fifty own Learning Centres and four national-level Colleges in the country, exposed to specialized training (named 'PARIVARTAN' - meaning 'CHANGE') with behavioral science inputs (corporate citizenship) to bring about attitudinal change through value education aiming at infusing corporate citizenship and loyalty to the organisation. Things improved remarkably, phenomenal change in staff attitudes were observed as customer service dramatically improved, and now the Bank is known for its efficient customer service and prompt handling of operations.

\section{Brief about Iran}

\section{Present Study}

A country situated in the Middle East and having major complement of Muslim population, Iran has many commonalities with the neighbouring Muslim countries. However, due to its unique historical, linguistic, and racial identities, it has developed a different and unique culture. ${ }^{\mathbf{1 4}}$ It is possible to consider two distinct vectors in Iranian culture: nationalist and Islamist. The nationalist aspect of Iranian culture is related to ancient Persian civilization, and Zoroastrianism heritage which dates back to 3000-2000 BC but it is still prevalent in different aspects of Iranian society such as Calendar, New Year Festivals (Nowrooz) and Persian literature. On the other hand, Islamist aspects are relatively younger and date back to the $7^{\text {th }}$ and sixteenth centuries BC. It has been suggested that besides Persian and Islamist influences, the effects of Western culture of Iranian society should be taken into consideration for proper understanding of Iranian society. ${ }^{\mathbf{1 5}}$ One of the features of Iranian culture is the high degree of hierarchical distance. This dimension concerns the extent to which the less powerful members of a society expect and accept that power is distributed unequally. Hofstede viewed Iran as a high power-distance society. ${ }^{16}$

Brief Profile of SAFA Industrial Group: The study is confined to the 'Safa Industrial Group' which is one of the pioneer company-groups in regard to production, business volume and new industrial development plans in hand - establishment of which at the present time by means of management and diplomacy of seven manufacturing and four commercial companies - is reckoned as one of the largest Groups in the private giants Groups, where more than 2000 individuals are directly active within the group. The manufacturing companies under the management and oversight of this group are: Saveh Rolling \& Profile Mills Co.; Safa Rolling \& Pipe Mills Co.; Ostad Industrial Group; Amol Industrial Group; Kashan Amir Kabir Steel Co.; Safatoos Rolling \& Pipe Mills Co.; and Soroush Rolling \& Galvanizing Mills Co., totally per year production capacity of 4 million tons, supplying the products in three functional key markets such as energy and industrial, constructional and automobile manufacturing.

Out of 266 respondents, there were $124(47 \%)$ in the age band of 20-30 and $127(47 \%)$ in the age group of 31-40 and the rest $15(6 \%)$ in the age band of $40-60$.

\footnotetext{
${ }^{12}$ Balaji.(2012). Maruti Episode in Manesar in Gurgaon.IJEMR. Issue No.8, August, 2012.

${ }^{13}$ Balaji.(2012). Maruti Episode in Manesar in Gurgaon.IJEMR. Issue No.8, August, 2012.

${ }^{14}$ Ali, A. J. and Amirshshi, M., “The Iranian Manger: Work Values and Orientations”, The Journal of Business Ethics, Vol. 40, No. 2, 2002, pp. 111-33.

${ }^{15}$ Bani-Asadi, H., Interactive Planning on the Eve of the Iranian Revolution", Ph.D Dissertation, University of Pennsylvania, Philadelphia, 1984

${ }^{16}$ Hofstede, G., Culture's Consequences: International Differences in Work Related Values, op. cit.
} 
Education-wise, regarding the distribution of Respondents in the age-group 20-30, there were 40 (15\%) with less than Diploma, 107 (40\%) with Diploma, 115 (42.5\%) with Degree or Diploma plus Degree, the rest 4 $(2.5 \%)$ were possessing Post Graduate Degree.

Job Experience-wise, the distribution of the respondents was as follows: there were $56(21 \%)$ in the age-group of 20-30 with one year experience; there were 47 (18\%)in the age-group of 31-40 with one year experience; there were $65(25 \%)$ in the age-group of 20-30 with experience of 2 years; there were $60(24 \%)$ in the age-group of 30-40 years with two years experience.

Job-wise, there were $88(\%)$ workers, $22(\%)$ supervisors, $2(\%)$ Managers and $2(\%)$ othersin the age-group of 20-30. There were 77 ( $\%$ ) workers, 39 ( \%) supervisors, $5(\%)$ managers and 6 others $(\%)$ in the age-group of 30-40. There were 6 workers $(3 \%), 4(2 \%)$ supervisors, $2(1 \%)$ managers and $3(1 \%)$ top managers in the age-group of 40-60.

The picture that emerges out of the above data is that majority of the staff is young say below 40 years. When we see the distribution experience-wise, the same picture emerges; the majority has experience of up to two years only. Perusing job-mix, we find that majority is in workers category followed by supervisors. Managers and top managers are very few.

The inference can be drawn that there is great need for training, motivation and to restructure the organisational set-up of the Group-companies by infusing modern methods of management and supportive practices to enhance the level of human capital and to catch up with the modern world. The present study should be useful to the 'SAFA' Group.

In this Article, the following dimensions have been considered as objectives to find out whether the following could be the methods for 'Development of level of Human Capital':

a). developing human resource capacities into positive thinking and behaviour by Education;

b).Development of level of Human Capital through Training and Development

c). Team-Work for developing Human Resource;

d). Participation for developing Human Resource;

e). Social Mobilisation for developing Human Resource;

f). Group Dialogue for developing Human Resource;

g). Responsibility Bearing for developing Human Resource;

h). Positive Thinking and Behaviour for developing Human Resource by changing HR policy, practices and the work-culture.

The following theses were formulated for this study in addition to the above objectives. An humble effort was made to test these hypotheses.

$\mathrm{Ho}_{1}$ : Work Habits Are Governed By Work Culture

$\mathrm{Ho}_{2}$ : Work Culture Can Be Maintained and Enhanced By Training and Development of the Human Resource

$\mathrm{Ho}_{3}$ : There is a Positive Correlation between Team Work and Organizational Commitment

$\mathrm{Ho}_{4}$ : There Is a Positive Correlation between Human Capital and Organizational Commitment (concerning Human Capital)

$\mathrm{Ho}_{5}$ : Use of Effective Employee Development Practices will enhance the Level of Human Capital (EmployeeDevelopment)

\section{Population, Sample Size and Selection of Sample}

Out of 2,000 odd employees, officials and senior people, only 266 were brought into the sample which, therefore, constituted the size for the study. Stratified random sampling technique was used to constitute the sample. The units - workers, supervisors, managers - were classified on the basis of age, education, status (responsibility levels), experience in terms of number of years' working in the organisation, origination (whether from local area or from city).

Methodology: A questionnaire was specially designed and data collected on that basis from the sampled workers and supervisors by administering it. On almost similar lines, a Schedule was designed for interview with the managers and supervisors who were entrusted with overseeing the functions at corporate/head offices of the Group companies in the 'SAFA' Industrial Group. Both the questionnaire and schedule were given duly translated in Arabi and Persian languages to avoid difficulty of understanding the contents. Statistical/mathematical tools were used like average, percentage, ANOVA, Cronbach Alpha, etc. for analyses and interpretations for arriving at the conclusion, and furnishing suggestions and recommendations.

\section{Analysis}

Out of 266 respondents, majority of them gave negative responses on Likert five-point scale, (Strongly disagree + disagree together), as under, when asked - 
i. Whether the ways or methods of developing human resource capacities into positive thinking and behavior by Education would be effective - responses were $49.5 \%$ 'No' and $13.5 \%$ remained neutral (no response).

ii. Whether team work was an effective way or method of developing human resource capacities into positive thinking and behavior - 'No' by $79.3 \%$.

iii. Whether their participation could be helpful in developing human resource capacities into positive thinking and behaviour - 'No' by $82.3 \%$.

iv. Whether responsibility bearing was an effective method of developing human resource capacities into positive thinking and behaviour - 'No' by $84.5 \%$.

v. Whether 'taking responsibility' was an effective way for developing appreciative positive thinking and behaviour - 'No' by $80.1 \%$.

vi. Whether Encouragement would beone of the effectivemethods of developing human resource capacities into positive thinking and behaviour - 'No' by $85.4 \%$.

vii. Whether Promoting Creativity was effective way for developing appreciative positive thinking and behaviour - 'No' by $80.4 \%$.

viii. Whether respecting others was an effective way for developing appreciative positive thinking and behaviour - 'No' by $83.9 \%$ ).

ix. Whether encouraging/enablingothers was an effective way for developing appreciative positive thinking and behaviour - 'No' by $82.3 \%$.

x. Whether converting problems into opportunities was an effective way for developing appreciative positive thinking and behaviour - 'No' by70.7\%). $70.7 \%$ ).

xi. Whether Social Mobilization was a method of developing human resource capacities into positive thinking and behaviour - 'No' by $70.6 \%$.

xii. Whether Coaching/Monitoring/Feedback would be an effective method in developing human resource capacities into positive thinking and behaviour - 'No' by $77.1 \%$.

The only positive response related to the following question:

Whether building of their capacities, strengths and best learning were more appropriate in human resource capacity building process and achieving development goals (66.2\%).

It proves that the respondents were keen on training for self-development and to turn over quality work and thereby also get satisfaction.

\section{Conclusion}

The respondents' opinion was asked about the methods by way of questionnaire as to whether those were effective way for developing appreciative positive thinking and behaviour among the workers. These were Education, team work,participation, responsibility bearing, taking responsibility, encouragement, promoting creativity, respecting others, encouraging/enabling others, converting problems into opportunities and social Mobilization, coaching/monitoring/feedback. The responses were 'No' by majority of them.

The only positive response was relating to: whether building of their capacities, strengths and best learning would be more appropriate in human resource capacity building process and achieving development goals $(66.2 \%)$. This is the only positive response and speaks for keenness on the part of workers to receive training (learning).

The responses of sample-workers under all the dimensions, except on 'Building Capacity, Strengths and Best Learning', were negative. An inference can be drawn that the workers are not engaged in conducive and congenial working environment and the 'Work Culture' in the Industrial Group has no concern for the personnel. Appropriate personnel policy and practices have to be worked out to motivate and support workers for promoting commitment, participation, responsibility-bearing attitudes for enhancing level of Human Capital. Communication channels and communication flow, both ways, have to be made open and interactive; suggestions may be invited, acknowledged and rewarded; House Magazine may be started and staff-activity related photos and news with photos may be published therein besides publishing write-ups on policy, practices and on the best performers.

For examining the hypotheses, Pearson Product Moment Correlation and Regression Analysis were used in addition to descriptive analysis was done (mean, variance, correlation and Cronbach Alpha) in regard to Hypotheses. Also, ANOVA was used as analysis tool. Hypotheses Nos. 1 to 5are proved:

It is inferred from the analyses that there is dire need in the Industrial Group (SAFA) toIntroduce Employee-Development practices, enhance Organisational Commitment, Introduce and strengthen Team Work through bringing in Participation, organising Self-Managing Teams (SMTs), setting up Quality Circles for trustbuilding and promoting corporate citizenship with autonomy; These strategies enrich work-culture and generate belongingnessand loyalty towards the organisation. It appears that pointed focus requires to be given to well- 
Planned and need-based/perceived training programmes on ongoing basis to infuse healthywork-culture and plan effort to enhance level of Human Capital.

The study shows that human resource management plays an important role in the management of the company. Work culture is the part of human resource management and it is affected by so many things which are important for the development of the company. Work habits are governed by work culture. Work culture can be maintained and enhanced by training and development of the human resource. There is a positive correlation between team work and organizational commitment. There is also positive correlation between Human Capital and organizational commitment. Use of effective employee-development practice can enhance the level of human capital. These all things are highly correlated to each other for the development of the company and its human development and management.

\section{Suggestions:}

(a). A Theoretical/Conceptual Framework is suggested below for achieving the broad objective of enhancing level of Human Capital. It needs hardy to emphasise that globalisation will soon intensify competition from the Multi-National Companies; their advent in the nation-states cannot be blocked for long. Those countries which resist the MNCs' entry will not be able to participate in the world economy and may remain technologically backward with their stagnant economies; standard of living of their citizens will remain low without access to benefits of modern science and technology.

\section{Proposed Theoretical/Conceptual Framework}

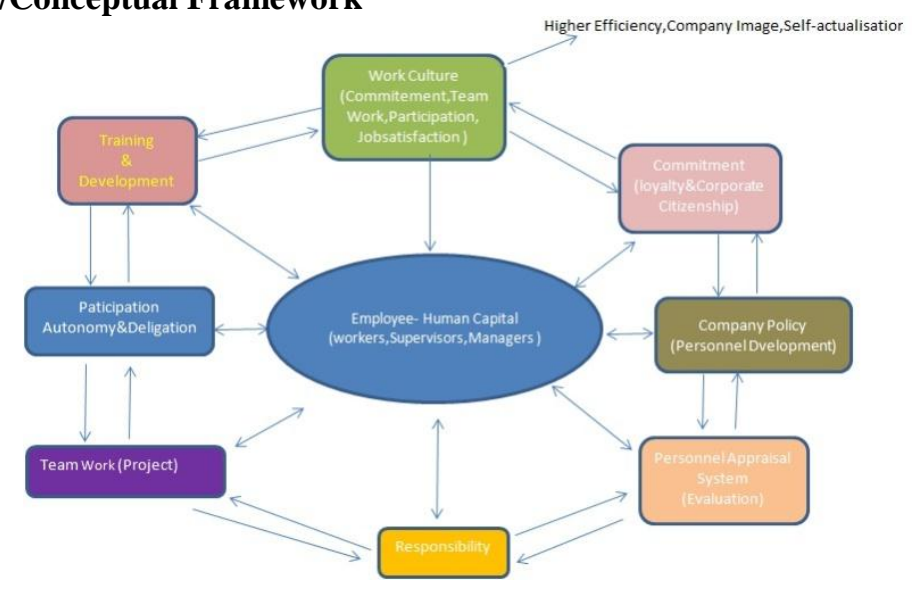

The suggested Theoretical/Conceptual Framework given above is self-explanatory. I hold strong opinion that company policies, work-culture, work-place environment are the foundations on which Human Resources cultivate conducive behaviour-patterns which bring in their trail highercommitment, team-work culture, enhanced productivity, improved results, interest in self-development, concern for career and development of corporate citizenship/loyalty. On such behaviour depends also the culture of Participation, Responsibility-bearing, Empowerment andneed for achievement of company objectives? Although Training and Development plays its part in raising level of all the aforesaid attributes/qualities yet Corporate Policy and Work-culture can neutralize the effect of Training and Development if these are in opposition or not supportive, and,overall, if conducive work-place environment is not in place in continuity. I strongly feel that formal and informal interactions with open door policy should help the organisation to promote organisational workculture; workers alone may not be able to bring about this transformation from bureaucratic to democratic environment and philosophy of working as a culture.

(b). There is scope of further studies in areas as company policies having bearing/influence on Work Culture; Training Needs Assessment; Job Satisfaction among Employees; Personnel Policies and Procedures relating to Employee-retention; Recruitment and Selection Process; Organisational Structure; Internal reporting System; Information Flow within the Organisation, etc.

\section{Recommendations}

From the data collected and processed, the analysis requires that -

(a). As the respondents were mostly ( $90 \%$ ) in the age-band of 25 to 50 and fell in the experience of up to 3 years $(65 \%)$, the SAFA Group may effect change in work culture, reduce the bureaucratic distance to create more cordial industrial relations by adopting open-door policy and inviting suggestions from the employees and by using grapevine (informal) communication. 
(b). Workers' Participation may be made broad-based and structured for healthy co-operation and better industrial relations.

(c). Self-managing Teams (SMTs) may be organised with responsibility to plan, execute and evaluate their work which would obviously be cheerfully accepted as this strategy would grant autonomy and delegation for proper execution of work.

(d). Quality Circles (QCs) may be organised to supplement the efforts of SMTs. The QCs will bring to management's notice the delays, faults in production, complicated and lengthy practices and systems followed, avoidable expenditures, and unnecessarily lengthy procedures of work, delayed transmission of information down the line up to the shop-floor level. The employees will rectify the faults and streamline procedures and change the systems and practices for better end-results.

(e). Education of employees will equip them better for understanding the perspectives and be aware of the latest trends in management, global business requirements. The workers/employees will getsensitised and they will realise their responsibilities as citizens, as employees and as partners in business/industry in which they would be employed. They will aspire to go up the career path through commitment, participation and adopting supportive work-culture.

(f). Training and Development is not one-shot action; it is a continuous process as changes in technology, markets, marketing and consumption-patterns are taking place at jet-speed. Not onlytraining, there has to be retraining and continuous interactions between workers and managers for solving problems amicably and in the spirit of complementarity of roles and on the basis of emotional bonding with the organisation.

\section{Bibliography \& References}

[1]. Agarwala, T. (2003). Innovative Human Resource Practices and Organisation Commitment: An empirical investigation International Journal of Human Resource Management. No. 14 (2), pp. 175-197.

[2]. Armstrong, Michael. (2001). A Handbook of Human Resource Management Practice, $8^{\text {th }}$ ed.Kogan Page, London.P.477.

[3]. Baldev, S. R. and Anupama, R. (2010). Determinants of Employee Engagement in a Private Sector organisation: An Exploratory Study. Advances in Management.No. 3, October, pp.52-59.

[4]. Baniya, LalBahadur. (2004). Human Resource Development Practice in Nepalese Business Organisations: A Case Study of Manufacturing Enterprises in Pokhara. The Journal of Napalese Business Studies.No. 1, December.

[5]. Birasnav, M. (2009).Structure of Human Capital Enhancing Human Resource Management Practices in India.International Journal of Business and Management. Vol. 4, No. 5, May.

[6]. Birasnav, M. and Rangnekar, S. (2008). A conceptual Model of Human Capital creation. In: D. S. Chundawat, K, Saxena, and S. S. Bhadu (Ed.) Managing Global Competition: A Holistic Approach. Macmillan, New Delhi. pp.261-273.

[7]. Boohene, Rosemond. (2011). The Effect of Human Resource Management Practices on Corporate Performance: A Study of Graphic Communications Group Limited. International Business Research.Vol. 4, No. 1, January.

[8]. Campion, M. A., Cheraskin, L. and Stevens, M. J. (1994).Career-related Antecedents and Outcomes of Job Rotation.Academy of Management Journal. No. 37, pp. 1510-1542.

[9]. Craig, E. F. and Hall, D. T. (2005). The new Organisational Career: Too important to be left to HR? In: Burke, R. J. and Cooper, C. L. (Ed.) Re-inventing HRM: Challenges and new Directions. Routledge, London.

[10]. David, James Clarke IV. (2006). The Nexus of Learning: The Intersection of Formal and Informal Education. Chief Learning Officer. No.5, February, pp. 22-25.

[11]. Galunic, D. C. H. \& Anderson, E. (2000).From Security to Mobility: Generalised Investments in Human Capital \& Agent Commitment. Organisation Science, 11, 1-20

[12]. Huselid, M. A. (1995). The Impact of Human Resource management practices on turnover, productivity and corporate financial performance. http:/www.marhhuselid.com/articles.html.

[13]. Iles, P. A. Nabey, C. and Robertson, I. T. (1990). Human Resource Practices and Employee Commitment: Possibilities, Pitfalls and paradoxes. British Journal of Management. No. 1, pp. 147-157.

[14]. Joanna, Krystyna and Lilian M. de Menezes.(2007). Human Relations.No. 60, p 987.

[15]. Jose, Geetha and Sebastian, Rupert Mampilly. (2012). Satisfaction with HR Practices and Employee Engagement: A Social Exchange Perspective. Journal of Economics and Behavioral Studies.Vol.4, No. 7, pp. 423-430, July.

[16]. Kahn, W. A. (1990). Psychological conditions of personal engagement and disengagement at work. Academy of Management Journal. No. 33, April, pp. 692-724.

[17]. Kalleberg, A. L. and Moody, J. W. (1994).Human resource management and organisational performance.American Behavioral Scientist. No. 37 (7) pp. 948-962.

[18]. Kohn, A. (1993). Why Incentive Plans cannot work. Harvard Business Review. No.71, pp. 54-60.

[19]. Lado, A. A. Wilson, M. C. (1994). Human Resource Systems and Sustained Competitive Advantage: A Competency- based Perspective. Academy of Management Journal. No. 19 (4), pp. 699-727.

[20]. Maimunah, I. and Lawrence, A. (2008). Workforce Diversity: A Human Resource Development Perspective towards Organisational Performance. European Journal of Social Sciences. No. 6, pp. 244-45.

[21]. MaranMarimuthu. (2009). Human Capital Development and its Impact on Firm Performance: Evidence From Developmental Economics; UluslararasiSosyalArastimanalarDergisi. The Journal of International Social Research. No 2(8), Summer.

[22]. Marler, J. H. (1998). The Effect of TQM Training, Flexible Work Technology on Continuous Improvement. Journal of Quality Management. No 3, pp. 241-264

[23]. Morishima, M. (1995).Embedding HRM in a social context.British Journal of Industrial Relations.No.33 (4) pp. 617-640.

[24]. Pati, S. P. and Kumar, P. (2010). Employee Engagement: Role of self-efficacy, Organizational support and Supervisor-support. The Indian Journal of Industrial Relations. No. 46, January, pp. 126-137.

[25]. Pfeffer, J. (1994). Competitive Advantage through People.Harvard Business School Press. Boston.

[26]. Raider, H. J. and Burt, R. S. (1996).Boundary-less Careers and Social Capital. In: Arthur, M. B. and Rousseau, D. M. (Eds) The Boundary-less Career: A new Employment Principle for a New organisational Era. Oxford University Press. Oxford. 
[27]. Rastogi, P. N. (2002). Sustaining Enterprise Competitiveness - Is Human Capital the Answer?,Human system Management. No. 19(3), pp. 193-203.

[28]. Rawal, Priyanka. (2009). Engaged Employees: Carrying High degree of Organisational Pride. HRM Review, ICFAI University Press. Hyderabad. Vol. IX, Issue VII, pp. 41-45.

[29]. Salas, E. and Cannon Bowers, J. A. (2001).The Science of Training: A Decade of Progress. Annual Review Psychology. No. 52, pp. 471-99.

[30]. Schein, E. (1996). Career Anchors Re-visited: Implications for Career Development in the $21^{\text {st }}$ Century. Academy of Management Executive. No. 10, pp. 80-88.

[31]. Shahnwaz, M. G. andJuyal, Rakesh, C. (2006). Human Resource Management Practices and Organisational Commitment in different Organisations.Journal of the Indian Academy of Applied Psychology. Vol. 32, No. 3, pp. 171-178.

[32]. Snell, S. A. Lepak, D. P. and Youndt, M. A. (1990).Managing the Architecture of Intellectual Capital: Implications for Strategic Human Resource Management. In: Ferris, G. R. (Ed.) Research in Personnel And Human Resource Management. No. S 4, pp. 15974.

[33]. Sohel, M. A. et al. (2003). The Impact of Human Resource management practices on operational Performance: recognising country and industry differences. ELSEVIER Journal of Operations Management. No. 21, pp. 19-43.

[34]. Soomro, R. B. Gilal, R. G. and Jatoi, M. M.(2011). Examining the Impact of Human Resources Management (HRM) Practices on Employee-Performance: A case study of Pakistani Commercial Banking Sector, Inter-disciplinary Journal of Contemporary Research In Business. No. 3, Issue 1, pp. 865-878.

[35]. Tayeb, M. (1998). Transfer of HRM Practices across cultures: An American Company in Scotland. The International Journal of Human Resource Management. No. 9: 2, pp. 332-358.

[36]. Tiwari, Pankaj. (2012). Human Resource Management Practices: A Comprehensive Review. Pakistan Business Review.January.

[37]. Tzafrir, Shay, HarelGedaliah S. Baruch and Dolan Shimon L. (2004).The consequences of Emerging HRM Practices for employees' Trust in their managers.Personnel Review, No. 33 (6), pp. 628-47.

[38]. Villanova, P. and Bernardin, H. J. (1989).Impression Management in the context of Performance Appraisal. In: Giacalone, R. A. and Rosenfield, P. (Ed.) Impression Management in the Organisation. Lawrence Erlbaum, Hillsdale. pp. 299-313.

[39]. Waal, A. A. de. (2007). Strategic Performance Management: A managerial and behavioural approach. Palgrave.Macmillan, New York.

[40]. Wilson, J. and Western, S. (2000). Performance Appraisal: An Obstacle to Training and Development? Journal of European Industrial Training. No.24, pp. 384-390. 